\title{
+Development of excellency-based curriculum: Evidences from integrated Islamic primary schools in Kediri
}

\author{
Suyitno Suyitno ${ }^{1 *}$, Ariesty Fujiastuti ${ }^{2}$ \\ ${ }^{1}$ STIE Indonesia Malang. Jalan Mega Mendung No.1-9, Kota Malang, Jawa Timur 65147, Indonesia \\ ${ }^{2}$ Universitas Ahmad Dahlan. Jalan Pramuka 42, Sidikan, Umbulharjo, Yogyakarta 55161, Indonesia \\ * Corresponding Author. E-mail: drsuyitno@yahoo.co.id \\ Received: 16 October 2017; Revised: 1 November 2019; Accepted: 11 November 2019
}

\begin{abstract}
This research was aimed to describe strategies of the excellent learning program and curriculum development plan, learning and curriculum implementation, and evaluation of learning and curriculum. This research used qualitative multisite study design with interactive analysis model (Miles and Hubberman, 1994). This research resulted: Integrated strategy of community needs assessment, team formulation, work meetings and shared decisions, and teachers development; Mental and physical process-focused, flexible and enjoyable learning model, and right brain-based Al-Qur" -the so-called WAFA, daily test with Al Qur'an Recitation Repetition Model, the so-called Munakosyah Tahfidz and Tilawah test, Criterion Reference Measurement mid and final tests.
\end{abstract}

Keywords: strategic management, curriculum development, excellent programs

How to Cite: Suyitno, S., \& Fujiastuti, A. (2019). Development of excellency-based curriculum: Evidences from integrated Islamic primary schools in Kediri. Jurnal Prima Edukasia, 7(2), 197-205. doi:https://doi.org/10.21831/jpe.v7i2.30323

d.

https://doi.org/10.21831/jpe.v7i2.30323

\section{Introduction}

To improve quality education means to improve the quality of its components which included standards and curricula, academic literature, teaching staff, system management, materials, as well as technical base (Kousainov, 2016). The curriculum is an essential component which has a strategic role in the education system, and learning processes are the core of school activities (Rusman, 2008). Management of curriculum and learning activities include in the process of planing, implementing and evaluating curriculum (Matry, 2008). Planning and Development of the National Curriculum are generally carried out by the Indonesian Ministry of National Education at the central level. The schools are obligated to implement, realize and adjust the curriculum with appropriate learning activities. In the case of the curricula local contents, the schools are invited to develop in accordance to the needs of the school, characteristic of their students, regional potential, and the needs of the community and the local environment.

Planning and development of the National Curriculum are generally carried out by the Indonesian Ministry of National Education at the central level. The schools are obligated to imple- ment, realize and adjust the curriculum with appropriate learning activities. In the case of the curricula local contents, the schools are invited to develop in accordance to the needs of the school, characteristic of their students, regional potential, and the needs of the community and the local environment.

The development of curricula shall follow the mandates of the Law of the Republic of Indonesia No. 20 of 2003 concerning the National Education System, article 36 paragraph 2 and of Government Regulation No. 19 of 2005 concerning National Education Standards (SNP) (Undang-Undang Republik Indonesia nomor 20 tahun 2003 tentang sistem pendidikan nasional, 2003; Peraturan Pemerintah Republik Indonesia no 19 th 2005 tentang Standar Nasional Pendidikan, 2005). The curricula shall be developed with reference to content standards, stated in the Indonesian Minister of Education Regulation No. 22 of 2006, and the competency standards of graduates of the educational unit, stated in the Indonesian Minister of Education Regulation No. 23 of 2006, and based on guidelines prepared by the National Education Standards Agency (BSNP). 
Jurnal Prima Edukasia, 7 (2), 2019 - 198

Suyitno Suyitno, Ariesty Fujiastuti

The development of diversified curricula has been a major challenge for schools. Even though the competency standards and graduates standards are centrally provided by the Indonesian Ministry of National Education, schools are not enrolled as the implementors, but as elaborator and developer of the contents covering the suitable local contents to deliver to the learners. In such a system, schools are made independent, qualified and have a social responsibility towards the surrounding community. This is the manifestation of decentralization in education. In this way, most of the tasks and responsibilities for conducting education were transferred to the regional government. The regional autonomy has implications for the independence of education, which impacts changes in the education management system. This finally impacts the determination for the type of curriculum contents.

The decentralized management system turned out to be complex since the local government and schools must change the ways they are working. In such a situation, it is challenging to employ with the formal education system. There appeared the most possibility to have participatory methods in developing the competency and curricula contents. In this case, students will get more personal attention.

In terms of school budgeting, the operational costs of the schools will increase tremendously. Moreover, when the education service quality raises better, the costs are becoming higher. On the other hand, in terms of the management of an educational institution, effectiveness and efficiency are absolute requirements for the success of the educational institution. Formal schools as non-profit organizations have experienced a lot of redefinition in terms of how schools should continue to operate in a hypercompetitive climate. This becomes the challenge of Islamic education, including Nurul Izzah Integrated Islamic Primary School At Gurah District and Nurul Islam Integrated Primary Schools at Pare District, East Java, Indonesia. From the preliminary study, it was found out that the two schools uniquely develop their educational quality through strategic management of excellent curriculum development program. These two schools have become the research sites with the following considerations: (1) both schools begins to develop their quality education by using excellent management curriculum development program, and (2) both schools have the vision and mission to become the flagship schools in Kediri Regency by continuously improving the excellent curriculum.

In the context of strategic management, Strategic management can be defined as the art and science of formulating, implementing, and evaluating cross-functional decisions that enable organizations to achieve their objectives (David, 2009). Strategic management is defined as the art and science of formulation, implementation, and evaluating functional decisions that enable organizations to achieve their goals. Strategic management focuses on integrated management. The main objectives of strategic management are to win the competition and to achieve organization successes. To work on these, an organization must develop specific competencies in the form of core capabilities, which include tangible resources such as physical and financial resources, and intangible resources such as repu-tation, technological excellence, product innova-tion, and so on. These resources are transformed into unique core capabilities in order to have competent creativity to answer challenges and have competitiveness. Strategic management at the academic area concerns with the competition in its own school organization and at the same time concerns the meta competence showing integrating skills competition (Rumelt et al., 1995). These are parts of the continuous improvement covering the procedures and results of assessment application and planning services. The strategic objectives of educational working practices include challenges of quality, equality, fitness-forpurpose of the curriculum and professional teaching. The strategies will meet the optimum level of the education system progress if the deep-seated change is established (Latorre-Medina \& BlancoEncomienda, 2013). The successful strategic management addresses (1) pedagogical issues, (2) the capacity for the person to deal with complexity and work effectively, (3) teamwork, (4) openness to deal with learning and innovation, (5) solutions for complex challenges, (6) bounded organization is working toward the future to reach the vision, and (7) strategic intervention system (Latorre-Medina \& Blanco-Encomienda, 2013). These components are essential in strategic management.

The curriculum as a functioning direction towards the teaching and learning process and the goals was achieved by the school and dynamic changes. Therefore, the school curriculum needs to be assessed and developed in accordance with the expectation of the community. The best curriculum development included (1) Ease of an 
Jurnal Prima Edukasia, 7 (2), 2019 - 199

Suyitno Suyitno, Ariesty Fujiastuti

objective analysis, (2) design of a program, (3) application of a series of related experiences, and (4) equipment and process evaluation (J. Wiles et al., 1989).

In contexts of the curriculum development processes, therefore the process of designing and developing a curriculum is a continuous chain process. Curriculum as a plan is essentially an effort to produce graduates, or change the input of students from the initial conditions into students who have criteria. The focuses are (1) able to understand the concepts underlying the competency standards that must be mastered, (2) being able to do work in accordance with the demands of competency standards that must be achieved by correct methods and procedures and good results, and (3) being able to apply their abilities in daily life (Muhaimin, 2005). Thus competence is a good combination of mastery of knowledge (knowledge), skills in carrying out work, and attitudes required to master the attitude of a job.

The curriculum development process can be divided into two types of processes, namely development in terms of engineering and development in the sense of construction (Hamalik, 2010; Sumarsih, 2010). The development process in the first sense consists of four stages; construction is returning the curriculum model that is expected to be based on that foundation; implementation is the implementation of the curriculum, and evaluation is to assess the curriculum in a professional and systematic manner.

In general, curriculum experts view curriculum activities as a continuous process and is a cycle that involves several components of the curriculum, namely the component goals, materials, activities and evaluations. Curriculum development, like a comprehensive process, includes planning, implementation, and evaluation activities (Subandijah, 1993). Referring to the curriculum development cycle mentioned above, it can also be seen that curriculum development is essentially the development of curriculum components that form the curriculum system itself, namely goals, materials, activities, and evaluations. This is done so that the curriculum can run according to what is expected in an effort to achieve the stated educational goals.

This excellence movement was then developed and embodied by education unit level education (school) managers in school forms that have a trademark in the community. For example, plus schools, excellent schools, natural schools, integrated schools, preparatory schools (laboratories), full-day schools, and other labels attached to schools are assumed by prioritizing Excellent programs.

Based on the viewpoint of the success of the school, it is then known to be active and efficient schools that refer to the extent to which schools can achieve the stated educational goals and objectives. In other words, the school is called dynamic if the school can make what has been planned. The general definition of effective schools is also related to the formulation of what must be done with what has been achieved. A school will be called useful if there is a strong relationship between what has been formulated to be done with the results achieved by the school. Otherwise, the school is said to be ineffective if the relationship is low. Effective schools are schools that are able to improve the mastery of teachers' knowledge and skills so they can help students learn as they should. Improving the ability of the teacher, developing the independence of students learning, conducting exploration, elaboration and confirmation in mastering information, applying knowledge in various learning products that are real and can be demonstrated in the form of oral, motion, and writing (Batubara \& Tanjung, 2019; Khoirunnisa, 2019; Merilia et al., 2019). Therefore, what is called an effective school is a school that has a good process, supporting education staff, good facilities so that it produces good output as well.

Reviewed from various references, according to Tobroni (2005), there are four categories of schools when viewed from the quality and educational process, namely: bad school, good school, active school and excellence school. Bad school is a school that has good or very good input, but the education process is not good and produces an output that is not qualified. A good school is a school that has good input, good processes and good results (output). An effective school is a school that has good/poor information, the education process is very good and produces good/excellent results. The excellent school is a school whose input is very good, the process is very good and produces excellent graduates.

An active school is a term to describe an ideal school. The term effective school, among others, is put forward by Preedy (1993) in his book "Managing the Effective", Davis and Thomas (1989) in his book "Effective School and Effective Teacher", (Frymier, 1984), in his book "One Hundred Good Schools, as well as many other experts. Other terms that mean ideal schools vary as good schools (good school or 
Jurnal Prima Edukasia, 7 (2), 2019 - 200

Suyitno Suyitno, Ariesty Fujiastuti

better schools) by K. Wiles and Lovell (1975), in the "Supervision for Better Schools" favourite school (favourite school), the flagship school (excellence school), successful schools, quality schools, pilot schools, model schools, elite schools, idol schools, expensive schools, hope schools and so on. Following are the opinions of experts about effective schools. The definition of the statement above can be understood that excellent school is one thing where the progress of students is better than the usually expected conditions. The effective schools are schools that provide more value to their students than other schools that have the same characteristics. Schools are geared to excellent schools by developing unique programs. Excellent schools have been defined as

One in which pupils progress further than might be expected from its intake. In other words, effective schools add extra value to other students in comparison with other schools serving similar intakes. In contrast, effective school is one that makes students less progress than expected, given their characteristic at intake (MacBeath \& Mortimore, 2001). Excellent schools are also meant as schools that are able to have the impact of learning to achieve all missions, showing a similarity in quality/quality. Excellent schools are schools that carry out their functions as the best place to learn by providing quality learning services for their students (Lezotte \& Snyder, 2011). The general definition of Excellent school is also related to the formulation of what must be done with what has been achieved. So that a school will be called Excellent if there is a strong relationship between what has been formulated to be done and the results achieved by the school, otherwise the school is said to be ineffective if the relationship is low.

According to the Indonesian Ministry of National Education (Depdiknas), schools are said to be good if they have eight criteria: (1) students who enter are rigorously selected and can be accounted for based on academic achievement, psychological tests and physical tests; (2) educational facilities and infrastructure are fulfilled and conducive to the learning process, (3) climate and supportive atmosphere for learning activities, (4) teachers and education staff have high professionalism and adequate level of welfare, (5) improvise curriculum so that it meets the needs of students who generally have a high learning motivation compared to their age students, (6) student learning hours are generally more extended because of the demands of the curriculum and student learning needs, (7) the learning process is more qualified and accountable to students and guardians of students, and ( 8) Excellent schools benefit the environment.

Based on this above description, the following research questions guided the research process: (1) How is the formulation of strategies in curriculum development and learning in excellent programs?, (2) How is the implementation of the strategy in curriculum development and learning in excellent programs?, and (3) How is the evaluation system for the implementation of curriculum and learning on excellent programs? Therefore, the aims of this research are to describe (1) the formulation of strategies in curriculum development and learning in unique programs; (2) the implementation of the plan in curriculum development and learning in excellent programs, and (3) the evaluation system for the implementation of curriculum and learning on unique applications.

\section{Methods}

This research used qualitative multi-sites design. Data were collected using interviews, observation, and documentation. Informed sampling was taken by using purposive sampling with the snowballing technique. Sites of this research were made by having criteria of the uniqueness of the schools. Two integrated Islamic primary schools named SDIT Nurul Izzah in Gurah and SDIT Nurul Islam in Pare Kediri District were chosen as the sites. Interviews were conducted by using an in-depth interview with probing techniques. During the data collection transcribing, coding, and summarizing interview contact was managed. The observation was done by having participative observation mainly in the focused observation after having descriptive and selective observations. Field notes and observation contact summary were made. The documentations concerns with the curriculum development, instruction, and evaluation documents. To equip the analysis, document contact summary was made. Data reduction was made for the purpose of attending to focuses on the research. Data were analyzed by using the Interactive Analysis model (Miles et al., 2014) and by using modified induction analysis (Bogdan \& Biklen, 2007). The analysis involved in site analysis and cross sites analysis.

To ensure the validity and reliability of the data checks of data credibility, confirmability, dependability, and transferability were taken. The credibility check was taken by using both 
Jurnal Prima Edukasia, 7 (2), 2019 - 201

Suyitno Suyitno, Ariesty Fujiastuti

source and technique triangulation and member check. The reliability and confirmability of data were checked by using a process audit. To ensure the transferability, this report was made systematic.

The cross-sites data analysis was aimed to compare and integrate findings obtained from each research site. In general, the process of analyzing cross-site data was as follows: (1) comparing results of the two sites to find similarity and note differences, (2) formulating propositions based on the findings of the first site and then continuing the second site; (3) comparing and integrate temporary theoretical findings from both research sites; and (4) formulating theoretical conclusions based on cross-site analysis as the final findings of the two research sites.

\section{Results and Discussion}

Result

Results of this research were presented in three subcategories, which were: (1) within each site analysis, (2) cross-sites analysis, and (3) propositions.

\section{Formulation of Strategies}

The wording of strategies in the development of the excellent program curriculum covered the formation of teamwork; program determination is favoured in the work meeting of the institution, coaching individually for teachers in collaboration with East Java WAFA, and preparation of learning devices. Findings at the second site, which was SDIT Nurul Islam revealed: the formulation of the strategies in developing the curriculum of the excellent programs including the establishment of a curriculum development team, analysis of context, teacher training in collaboration with East Java WAFA, and preparation of learning tools.

In the formulation strategies, management to design a comprehensive plan is prevalent, involving any stakeholder of involved school communities. Teachers, as the first actor, receive priority, and principals supervise how umtilamet goals of the excellent program should be targeted and how curriculum contents should be developed in line with the objectives. In addition, learning outcomes that support the National Curriculum Framework are identified considerably. The formulation was developed through a reliable team weak, coordination meetings, and finally providing training to the selected teachers involved in the group. This way, identification of problems, obstacles, the focus of teaching contents, teaching materials, and how the curriculum is set can be achieved accordingly.

The principal at site 1 says:

"We are committed to designing an excellent program where Islamic contents are emphasized. We see many problems in our internal staffs, but we have to show our accountability that our excellent program has the distinction. So, we have teamwork who design and make acceleration on curriculum and its implementation."

Thorugh the training for teachers that involved provincial authority, the problem is resolved through the work of the team. Solid preparation has been developed in stages from the initial development to the results of hard work by the organisation.

Principal at site 2 describes:

"The preparation that involved all parties are the most crucial. We identify the problem, analyze the context, collecting donators, focusing on the excellent programs and visualizing the programs into the curriculum and schools activities are achieved in the formulation of the program. I highly appreciate the team that has demonstrated the excellent program at our school".

\section{Implementation of Excellent Program}

The application of the excellent program curriculum is characterized by the learning process that is designed correctly to provide experiences that involve mental and physical processes through interaction between students and teachers, to accelerate learning for each individual, a learning service model must be developed that allows students to learn continuously, so that the teacher must prepare and design learning that is flexible and enjoyable with an effective and efficient learning plan, and to improve the quality of teachers with regular coaching every week, and participating in various trainings and workshops.

A teacher at site 1 describes that in the implementation stage, the core purpose of how to achieve the standard of the teaching process is very important. There should be hard work to prepare students in reading $\mathrm{Al}$ Quran and to serve discipline of attitude in the whole process.

"We have a commitment to training students with high performance on reading and learning $\mathrm{Al}$ Quran because our main goal of 
the excellency is to serve students memorize the al Quran. Our students are not all well prepared. So, we serve them not only how to read the Al Quran correctly but also to prepare attitude and the discipline of the students. We have teamwork that demonstrates our commitment better."

\section{Evaluation of the Program}

The evaluation of the implementation of the Al-Qur'an's excellent program curriculum was: Repeating the page carried out by the companion teacher of the Qur'an, Testing volumes are tested by the coordinator of the Qur'an, munakosyahTahfidz and tilawah were tested by the East Java WAFA Team, midterm examination, and final examination. All evaluations were used to measure student success and are used as feedback for students.

The evaluation of the implementation of the Al-Qur'an's excellent program curriculum was Daily Examination, namely the repetition of the pages carried out by the companion teacher of the Qur'an, testing volumes are tested by the coordinator of the Qur'an, MunakosyahTahfidz and Tilawah are tested by the East Java WAFA TEAM, midterm examination, and final examination. The evaluation consisted of two things, namely the first Al-Qur'an team internal evaluation (page increase evaluation, volume increase, munakosyah) which has certain criteria and the second is an evaluation that follows the service schedule, midterm test and final test. All evaluations are used to measure student success and be used as feedback for students

Based on these findings, the following propositions were built (1) Minor proposition 1: If the strategy formulation in the development of excellent curriculum programs is carried out with the formation of a curriculum development team, it will support the development of Excellent program curricula, (2) minor proposition 2: If the implementation of the excellent program curriculum is carried out with the learning process designed to provide experience, it will support the development of excellent program curricula, (3) Minor proposition 3: If the evaluation of the implementation of the excellent program curriculum is carried out in the form of summative and formative evaluations, it will support the development of excellent program curricula, and (4) Major Proposition: If the strategy formulation in the development of excellent curriculum programs is carried out by the establishment of a curriculum development team, the implementa- tion of the excellent program curriculum is carried out with the learning process designed to provide experience.

An assessor of the provincial team of East Java explains:

"The function of evaluation is so crucial. Four kinds of test are designed to check students' progress after students are specifically trained in Al Quran. They are munakosyah tahfidz to see the overall achievement on reading $\mathrm{Al}$ Quran by memory, sari tilawah to see the reading $\mathrm{Al}$ Quran by correct voice and rhythm, each of which is evaluated in term of a midterm test and in the final test. The standard of testing is determined by the provincial team of East Java whose are the al Quran expert on tahfid and sari tilawah.”

\section{Discussion}

This study has investigated how excellent programs have been developed in two schools, SDIT Nurul Izzah and SDIT Nurul Islam. In brief, the results show that to serve the unique programs, both schools shared a series of activities planning, implementing and evaluating. In the planning stage, concepts of excellent program are defined through the teamwork and training for teachers. The implementation stage focuses on the teaching process of the unique program and how teachers achieve the learning outcomes. In the evaluation process, the emphasis is developed to see the practice of Quran in terms of sari tilawah and reading of Quran. As for the discussion, each stage will be discussed below.

The formulation of strategies in curriculum development at SDIT Nurul Izzah Gurah and SDIT Nurul Islam Pare is oriented on student character building. According to Arifin (2011) planning is the process of preparing, determining and utilizing resources in an integrated and rational manner so that the activities to be carried out can run effectively and efficiently in accordance with the expected goals. The orientation of curriculum development planning at these schools is determined based on the learning needs of students. All students have the opportunity to learn to foster behavioural changes that lead to the readiness of participants to return to the community.

According to (Audrey \& Howard, 1972; Hamalik, 2010; Oliva, 2008) planning of learning opportunities is intended to bring about certain desired pupils and assessments of the extent to 
Jurnal Prima Edukasia, 7 (2), 2019 - 203

Suyitno Suyitno, Ariesty Fujiastuti

which these changes have taken place. It is intended that curriculum development is planning learning opportunities to bring students towards the desired changes and assess the extent to which these changes have occurred in students. Learning opportunities are the relationship between students, teachers, materials, equipment, and the environment in which the learning process is carried out. In agreement, (Katuuk, 2014) revealed that some strengthening steps as a strategy to strengthen the success of curriculum implementation were the planning, main and supporting resources, learning processes in schools, monitoring and evaluation activities. Teachers, school principals, facilities and infrastructure, as well as the school climate or culture and the participation of all relevant parties, play an important role in achieving successful implementation of the new curriculum.

The actual curriculum implementation takes place in the learning process. Some aspects found in research at SDIT Nurul Izzah and SDIT Nurul Islam indicate that what needs to be strengthened in learning in schools includes the learning process. The learning process is designed properly to provide experiences that involve mental and physical processes through interactions between students and teachers, to accelerate learning for each individual, a learning service model must be developed that allows students to learn continuously, so the teacher must prepare and design flexible and enjoyable learning with effective and efficient learning plans, and to improve the quality of teachers with regular coaching every week, and participate in various training and workshops. Masithoh (2018) listed the obstacles in learning success are: teachers have different capacities in understanding the scientific approach, teachers suffer from time constraints in designing class administration, and sometimes the activities that have been designed in the unit plan must replaced with something more in line with the theme. On the other hand, the constraints of students are as follows: students have various capacities, students have different learning styles, and some students need special assistance in attending the learning process. Despite these obstacles, teachers always evaluate the learning process so students will be more motivated to pursue their aspirations with support from a good environment. Also, Katuuk (2014) advocated that teachers' ability to develop learning strategies can be prepared in two ways, namely increasing their knowledge of various approaches, models and innovative learning strategies, where this can be obtained through various education and training.

Evaluation in the curriculum is carried out in some ways, such as by developing ideas, formulating problems encountered, seeing the implementation of activities, and seeing the results and effects that have an impact on the program. The evaluation carried out on the implementation of program curriculum at SDIT Nurul Izzah, and SDIT Nurul Islam was on one flagship program, namely Al-Qur'an education. This evaluation was carried out through reading the holy Qur'an, testing the reading volume of Alquran by the provincial team of Munakosyah Tahfidz and Tilawah, midterm test, and final exam. All evaluations are used to measure student success and are used as a feedback step for students. (Supriyadi, 2017) admits that assessment is carried out systematically and continuously through placement tests, formative, diagnostics and summative. The implementation procedure is in accordance with the objectives and learning sequences with the principle of integrating assessment and learning process. Assessment is the process of acquiring/gathering information about student learning outcomes that are used as a guide for making academic decisions about students, providing information to students, parents, teachers, or other relevant parties about student learning progress, their strengths and weaknesses, to determine the effectiveness of learning and curriculum, and inform policy.

\section{Conclusion}

This study is intended to see three aspects of the excellence curriculum, defined from the formulation of strategies in curriculum development and learning in excellent programs, the implementation of the strategy in curriculum development and learning in excellent programs, and the evaluation system for the implementation of curriculum and learning on excellent programs. In summary, the findings indicate that curriculum management at Islamic schools under study are satisfied.

The main element in the planning of excellent program curriculum development is human resources and the common vision of all existing elements. In the implementation of excellent curriculum development, the learning process is designed to provide experiences that involve mental and physical processes through interaction between students and teachers, learning service models that enable students to 
learn continuously, so that the teacher must prepare and design flexible and enjoyable learning with a plan effective and efficient learning, routine teacher training every week, competency testing through WAFA certification and various training and workshops. In addition, the evaluation of the excellent program curriculum was carried out with daily tests, namely the repetition of the pages carried out by the Al-Qur'an companion teacher, the test of the rising volumes tested by the Al-Qur'an coordinator, munakosyah tahfidz and tilawah tested by East Java WAFA TEAM, midterm examination and final test.

\section{References}

Arifin, Z. (2011). Konsep dan model pengembangan kurikulum. PT Remaja Rosdakarya.

Audrey, N., \& Howard, N. (1972). Developing a curriculum. UnWin Education Books.

Batubara, R. E. N., \& Tanjung, S. (2019). Pengembangan alat tes kemampuan menyimak (compréhension orale) DELF tingkat A1 berbasis web. Arisen: Assessment and Research on Education, 1(2), 59-73. https://doi.org/10.33292/arisen.v1i2.45

Bogdan, R., \& Biklen, S. K. (2007). Qualitative research for education : an introduction to theories and methods. Pearson A \& B.

David, F. R. (2009). Manajemen strategis konsep. Salemba Empat.

Davis, G. A., \& Thomas, M. A. (1989). Effective schools and effective teachers. Allyn \& Bacon.

Frymier, J. R. (1984). One hundred good schools. Kappa Delta Pi.

Hamalik, O. (2010). Kurikulum dan pembelajaran. Bumi Aksara. https://doi.org/2010

Katuuk, D. A. (2014). Manajemen implementasi kurikulum: Strategi penguatan implementasi Kurikulum 2013. Jurnal Cakrawala Pendidikan, 1(1). https://doi.org/10.21831/cp.v1i1.1858

Khoirunnisa, W. (2019). The use of frontloading strategy in teaching vocabulary. Universitas Islam Negeri Syarif Hidayatullah Jakarta.

Kousainov, A. K. (2016). The ways of improving the quality of the secondary education in the Republic of Kazakhstan. SHS Web of Conferences, $29, \quad 01036$. https://doi.org/10.1051/shsconf/20162901 036

Latorre-Medina, M. J., \& Blanco-Encomienda, F. J. (2013). Strategic management as key to improve the quality of education. Procedia - Social and Behavioral Sciences, 81, 270274.

https://doi.org/10.1016/j.sbspro.2013.06.4 26

Lezotte, L. W., \& Snyder, K. M. (2011). What effective schools do: Re-envisioning the correlates. Solution Tree Press.

MacBeath, J., \& Mortimore, P. (2001). Improving school effectiveness. McGrawHill Education (UK).

Masithoh, D. (2018). Teachers' scientific approach implementation in inculcating the students' scientific attitudes. Jurnal Prima Edukasia, 6(1), 32. https://doi.org/10.21831/jpe.v6i1.14282

Matry, M. N. (2008). Implementasi dasar-dasar manajemen sekolah dalam era otonomi daerah. Aksara Madani.

Merilia, S., Fajaruddin, S., \& Arbain, A. (2019). An assessment of an English textbook of vocational school. Arisen (Assessment and Research on Education), 1(2). https://doi.org/10.26486/ARISEN.V1I2.4 6

Miles, M. B., Huberman, A. M., \& Saldaña, J. (2014). Qualitative data analysis: A methods sourcebook. Sage.

Muhaimin, H. (2005). Pengembangan kurikulum pendidikan agama Islam. Raja Grafindo Persada.

Oliva, P. F. (2008). Developing the curriculum. Pearson.

Preedy, M. (1993). Managing the effective school. SAGE.

Undang-Undang Republik Indonesia nomor 20 tahun 2003 tentang sistem pendidikan nasional, Pub. L. No. 20, Undang-Undang Republik Indonesia 26 (2003).

Peraturan Pemerintah Republik Indonesia no 19 th 2005 tentang Standar Nasional Pendidikan, Pub. L. No. 19 (2005).

Rumelt, R. P., Schendel, D., \& Teece, D. J. (1995). Fundamental issues in strategy: A research agenda. Rutgers University Press.

Rusman, R. (2008). Manajemen kurikulum. Rajawali. 
Jurnal Prima Edukasia, 7 (2), 2019 - 205

Suyitno Suyitno, Ariesty Fujiastuti

Subandijah, S. (1993). Pengembangan dan inovasi kurikulum. PT RajaGrafindo Persada.

Sumarsih, S. (2010). Rancangan kurikulum berwawasan kemanusiaan. Jurnal Pendidikan Akuntansi Indonesia, VIII(1), 22-30.

Supriyadi, E. (2017). Pengembangan model evaluasi untuk meningkatkan mutu pendidikan teknik elektro. Jurnal Edukasi Elektro, https://doi.org/10.21831/jee.v1i1.13254

Tobroni, T. (2005). The spiritual leadership. UMM Press.

Wiles, J., Bondi, J., \& Guo, H. (1989). Curriculum development: A guide to practice. Merrill Publishing Company Indianapolis, Indiana.

Wiles, K., \& Lovell, J. T. (1975). Supervision for better school. Pritice Hall. 